\title{
The Legal Status and Responsibility of the State Corporations in the Russian Federation
}

\author{
Saglar S. Ashtaeva \\ Kalmyk state university, Kalmykia, Russia \\ Email: eldirect@mail.ru, ashtaeva.s@rambler.ru \\ Jury S. Ashtaev \\ Rostov state University of railway engineering, Rostov, Russia \\ Kermen V. Lidjeeva \\ Kalmyk state university, Kalmykia, Russia \\ Georgiy L. Rubeko \\ Kalmyk state university, Kalmykia, Russia
}

Doi:10.5901/mjss.2015.v6n3p200

\section{Abstract}

An important feature of the activities of corporations with government participation is a unique legal status that provides breakes and allows to pursue the dominant policy in a number of industries of strategic importance and of innovative nature for the country. The priority was the concept of special and not contractual nature of corporate relations. The result of decided difference was large-scale changes in the legislation of the Russian Federation on legal entities. The changes affected not only the Civil Code of the Russian Federation but also the Federal law of 08.02.1998 No. 14-FL "On limited liability companies" (The Federal law from 08.02.1998 No. 14-FL (edit. on 05.05.2014) "About societies with limited liability", 2014), the Federal law dated 26.12.1995 No. 208-FL "On joint stock companies" (Federal law dated 26.12.1995 No. 208-FL (edit. on 22.12.2014) "On joint stock companies", 2014). The article discusses some of the characteristic features of the organizational-legal form, powers and functions of the state Corporation, legal differences corporations and business entities. In addition, the form of ownership, as well as the issues of exclusion of civil liability of the state Corporation are considered.

Keywords: state corporation, joint stock company, a business entity.

\section{Introduction}

State Corporation as a special legal form has all the necessary characteristics of a legal entity under Russian law, both legal - acts independently in the civil turnover; is responsible for its obligations belonging to it by right of ownership of property, and so on, and the material - has internal organizational unity and external autonomy inherent property separateness.

At the same time for public corporations are characterized by several features, contributing to the specificity of the legal form of the legal entity:

1) non-commercial character of Corporation, which means the absence as a main purpose of activity for profit, the use of secured profit only in the performance of statutory functions and, as a consequence, there is no obligation to transfer profit to founder (p. 1 Art. 50 of the CC of the Russian Federation (Civil code of the Russian Federation (part one) from 30.11.1994 \# 51-FL (publ. on 22.10.2014), 2014), p. 3 Art. 26 of the Federal law of January 12, 1996, № 7-FL "On non-profit organizations» (Federal law dated 12.01.1996 №. 7FL (edit. on 31.12.2014) "On noncommercial organizations", 2014));

2) the founder of the state Corporation is Russian Federation, which means that no one, except the Russian Federation, has no authority to manage the Corporation and to oversee its activities. In its turn, the state may not terminate its Foundation, without eliminating the;

3) the public nature of the activity, because the Corporation carries out it in the interests of the whole society and 
to solve socially significant problems;

4) strictly special-purpose character of the activity and use of property;

5) the formation, operation and termination of the existence on the basis of special laws;

6) the absence of necessity to have incorporation documents; the regulation by law of the procedure for the formation of management bodies and the appointment and dismissal of officers of the Corporation; a special form of reporting the results of operations;

7) after making the property contribution of the state Corporation Russian Federation loses freehold interest in this property which is transferred to the Corporation.

\section{Materials and Methods}

Today, neither in science nor in practice there is no consensus regarding the content of the concept of "Corporation". Usually it refers to: Association of persons on the basis of membership, as an Association of persons and capital; association of only capitals (business entities). It must be considered that the division of legal entities under the criteria of the membership corporations, and institutions still has not received legislative recognition in Russian law. It is an element of the doctrine of the remaining disputed on the merits.

First, if we talk about institutions, they are traditionally recognized as independent legal form, and not as legal persons. The same can be said about corporations

Secondly, for example, the business entities, established by one founder, cannot be regarded as associations.

Thirdly, the concept of "membership" in the Russian legislation is used mainly in relation to non-profit organizations, and commercial organizations only in relation to production cooperatives (art. 107 of the CC of RF).

In addition, membership exists in the peasant (farmer) farms that are not recognized as legal entities (p. 3 art. 1, art 14 of the Federal law of June 11, 2003, № 74-FL "On peasant (farmer) economy") (Federal law dated 11.06.2003 №. 74-FL (edit. on 23.06.2014) "On peasant (farmer) economy", 2014).

From this follows that, for example, the business entities, which are the pooling of capitals, can't be classified as corporations.

Taken into account the above-stated, it can be concluded that the determining factor in this case is not the terminology, but the powers of state corporations and the functions that they perform. Here, the legislator used the term "Corporation" not in the traditional sense, but as a synonym for the term "organization". Using by the legislator for denotation of considered legal form of the legal entity of the term "state" is, in fact, reflects the fact that the property of the state corporations initially formed at the expense of the state, which they controlled, and used for the purposes established by law. And the activities of public corporations aimed at implementing the objectives of the state in the relevant legislative acts (OECD Guidelines on Corporate Governance of State-owned Enterprises, 2005).

Also in favor of the use of the term "state" speaks socio-public orientation of functions of corporations, the order of formation of their Supreme bodies of management and control over the activities of these organizations.

In the Russian Federation are set up and are functioning legal entities, legal form of organization of which does not fit into any of the existing forms of commercial or non-commercial organizations of civil legislation. This, in particular, is the Bank of Russia, the Pension Fund of the Russian Federation, social insurance Fund, compulsory health insurance Fund. A distinctive feature of such legal entities is mainly public nature of their functions and their tasks, the successful implementation of which form the substantive basis for the effective functioning of the society and the state.

This allows you to recognize as quite reasonable and realizable offers for the introduction in the Russian legislation the known legal systems of several countries the category of legal entity of public law with the possibility of their existence in various forms, relevant socio-economic characteristics of the tasks for which they are intended.

The analysis allows to identify the following main features of the legal entity of public law:

- it is created by the state without the participation of individuals;

- the legal basis of its formation and functioning is a public legal act;

- $\quad$ it is the carrier of the public will, public rights and duties, for what it is vested with authority. Such authority may be of operative, administrative or other character, but in the broadest sense it is the management authority. They are discretionary, i.e. decision of the legal entity of the public law, accept at their discretion, but within the law, apply to third parties;

- the capacity of such person is special, target and suggests the focus on the implementation of the public policy interests.

However, the issues relating to civil-legal status of legal entities of public law of their creation, registration, management, grounds and procedure for prosecution, the legal status of their property and other should be in more 
details and legislatively regulated.

One of the most important considerations when discussing the legal status of public corporations, is the question of the legal nature of the transferred property.

Federal law "On nonprofit organizations" and Federal laws regarding the establishment of public corporations establish that the state transfers to the corporations the ownership of property in the amount necessary for the successful implementation of the assigned to the appropriate Corporation social, managerial, or other socially useful functions.

In Art. 209 of the CC of RF the right of property is revealed through traditional civil rights triad of powers: possession, use and disposal. Accordingly, a public Corporation, like any other owner, shall be entitled to make in respect of its property any action, not inconsistent with law and other legal acts, and not violate the rights and legitimate interest of others.

Opponents of the Institute of public corporations unreasonably appreciate the act of transfer of state property into the ownership of these entities as an example of illegal "privatization" of this property.

However, at privatization happens the alienation of state property into private property. This circumstance plays a crucial role in determining the actual content of the right of ownership of public corporations on passed to them property.

Unlike a private Corporation owners can exercise their right to own not at their own discretion, but only for the purposes, which is set before them by the legislator, i.e. ultimately by society and the state. At the same time happens the exclusion of the turning of results of the possession, use and disposition of this property in their favor in the sense that the inherent understanding of the benefits in the format of entrepreneurial activity: all profits derived by the Corporation from the investment of surplus funds, securities, etc., can be directed only to the solution of problems for which it was created.

Strictly speaking, as the government Corporations are created by the state and there is no other founders, it cannot be said that the donation of corporations property forever go out of state ownership. As a matter of fact, this refers to the transfer of state to legal person of authority for state property management. This, in particular, shows a certain ambiguity in the legal regime of property of public corporations. On the one hand, this property is embodied in law as property of legal entities, and on the other, the real powers of the owner are in the hands of governments, consisting of civil servants.

In this respect it is significant that the state reserves to himself the decision on the fate of the property of the state Corporation, including its liquidation.

For example, part 2 Art. 18 of the Federal law "On the state Corporation "Russian technologies" provides that the property of this organization after its liquidation proceeds in Federal ownership. This suggests that the status of public corporations in this respect similar to the status of fiduciary owner of the property allocated to such owner by a third party (in this case the state).

Essentially, all this means that form of ownership of public corporations does not apply to classic forms, enshrined in p. 2 art. 8 of the Constitution of the RF (The Constitution of the Russian Federation (adopted by popular vote 12.12.1993), 1993) and p. 1 art. 212 of CC of the RF (public, private, municipal), but can be qualified as provided by the specified standards of different ownership or as another kind of public property along with the state and public.

This issue needs further comprehensive study, and the status of assets of public corporations should be clarified legislatively.

The analysis of the peculiarities of the legal status of public corporations suggests the need to consider their socioeconomic entity, due to the content of the tasks for which they are created. This raises the question if could the functions assigned by law to the Corporation be independently implemented, on the one hand by government agencies, and on the other business entities, in particular the joint.

In principle, all without exception these functions to some extent are already implementing and the tasks ultimately will be decided only by the state. However, the Soviet experience convincingly demonstrated organizational inefficiency, economic overinvestment and strategic futility of this approach, not mentioning its complete incompatibility with current market realities.

However, the market, as demonstrated by the Russian practice of recent years, is not able to solve the system of strategic socio-economic problems, which have national, public value. Business in the face of equity and other commercial business companies finds the main purpose in making a profit. But the process of solving these problems, as a rule, has long-term character, involves huge investments, exceptional organizational efforts, is impossible without the availability of administrative powers, and even if they have a commercial perspective, do not guarantee a quick return on capital. Thus, the business, even under condition that such tasks on its financial, organizational, moral potential are within its power (in Russian business is not obvious), objectively not interested to take care of all the fullness of the social and, not least, political responsibility, and economic risks associated with their decision.

Mainly the comprehension of the state of the fact that the solution of some vitally important for Russia's socioeconomic objectives is not achieved and cannot be achieved without adequate material and other costs in the traditional 
forms of legal entities, led to the establishment of public corporations as a natural process, driven by the needs of socioeconomic development of modern Russia. As legal entities of public law, they are instruments of indirect regulatory impact of the state on public relations. Of course, their creation is directly linked with increased role of the state in their regulation. Being legal entities of public law, they are instruments of indirect regulatory impact of the state on public relations. Of course, their creation is directly linked with increased state role in their regulation. But at the same time in the laws for the creation of corporations is consistently secured market component of this regulation: state Corporation within its competence are involved in the solution of the above-mentioned problems of the Russian business in the appropriate market conditions.

The expediency of establishing of public corporations was analyzed on the example of activity of the state Corporation "Agency for deposits insurance" on the implementation of its functions - the insurance of the deposits of citizens, rehabilitation and liquidation of banks. Also the business is poorly managed with a function for the implementation of competitive management (liquidation) banks, meaning not the satisfaction of self-interests, but the problem essentially solving.

In the end, based on the foregoing, it can be concluded that in the modern social, economic, political conditions, the most appropriate way of ensuring the implementation of a separate state government objective is the establishment for these purposes, public corporations as legal persons with special competence. The latter means that they have a unique combination of strictly target standing with the public nature of the task and the vesting in a particular amount of power.

Ongoing around the state corporations theoretical disputes can have serious practical social, economic and even political consequences. The proposed changes will require significant resources to implement and will result in a corresponding loss of time, which the state cannot afford in the fast (and sometimes unpredictable) changing situation in the global and Russian economy.

The state Corporation is liable for its obligations with all its property, which according to the legislation of the Russian Federation may be levied, that is to have solely independent property liability, the limits of which are determined by the value of the property owned government Corporation of the right of ownership. Therefore, a state Corporation is not liable for the obligations of its founder - the Russian Federation - as well as the founder of the state Corporation is not liable for the obligations of the latter (p. 2 art. 25 of the Federal law "On noncommercial organizations"). This rule is enshrined in the Federal laws that created state Corporations.

In some cases, failure of the property of the state Corporation are entitled to rely on additional funding for activities related to the main activity. For example, the performance of the obligations under the compulsory insurance of deposits may be carried out on the offer of the Board of Directors of the Agency at the expense of the reserve Fund of the Government of the Russian Federation (article 40 of the Law). In case of confirmation by the Board of Directors of the Agency decision of the management Board of the Agency of the impossibility of compensation on deposits on time without replenishment of the Fund of obligatory insurance of deposits due to additional funds (excluding insurance premiums and other scheduled receipts) the Board of Directors of the Agency, within a period not exceeding seven calendar days after the insurance event, takes one of the following decisions:

1) to apply to the Government of the RF with a request for allocation to the appropriate Agency funds as fiscal loans. The government of the Russian Federation shall take an appropriate decision;

2) to apply to the Government of the RF with a request for allocation to the Agency with additional funds from the Federal budget. At impossibility to allocate these funds to the Government of the Russian Federation in the framework of its powers contributes to the State Duma of the Federal Assembly of the Russian Federation the draft Federal law on introducing relevant amendments to the Federal law on the Federal budget for the respective year (art. of Law 41).

Similar legislative language may indicate the presence of joint responsibility of the founder-state debts of the Corporation.

In the Civil code of the Russian Federation, the legislator representing the formula of joint responsibility, establishes that before a claim against the person who, in accordance with the law, other legal acts, or the terms of the obligation shall bear liability in addition to another person, which is the principal debtor, the creditor must present a claim to the primary debtor. But only if the principal debtor has refused to satisfy the creditor or the creditor has not received from him within a reasonable time response required, this requirement can be presented to the person bearing subsidiary liability (p. 2 art. 399 of the CC of the RF).

Joint responsibility may be established by law, other legal acts (decrees of the President of the Russian Federation, decrees of the Government of the Russian Federation) or the terms of the obligation, the latter should be understood as the terms of the contract. Depending on the reason of attracting additional debtor to subsidizing, 
responsibility can be divided into statutory, contractual and tort. Statutory joint responsibility - responsibility of founders (participants), the owner of the property of a legal person or other persons who have the right to give mandatory for the entity specified or have the opportunity otherwise to determine its validity. The cases of statutory joint responsibility are:

1) subsidiary responsibility of founders (participants), owners of the legal person or other persons who have the right to give mandatory for the entity specifying or otherwise have the ability to determine its validity, the obligations of a legal entity upon its insolvency (bankruptcy) in the case of an insufficiency of assets (p. 3 art. 56 CC of the RF);

2) subsidiary responsibility of the General partner, who became a participant (shareholder) of the company or a member of a production cooperative in the conversion of the partnership, respectively, in the company or a production cooperative, the responsibilities transferred to the company or a production cooperative from the partnership. The ability to attract vicarious liability is valid for two years (p. 2 art. 68 CC of the RF);

3) subsidiary responsibility of participants in a full partnership and of the General partners in the limited partnership for obligations of the partnership, including; occurred prior to their entry into the partnership. Participant, retired from the partnership, is responsible for the obligations of the partnership incurred before the date of his retirement, along with the remaining participants within two years from the date of approval of the report on the activities of the partnership for the year in which he retired from the partnership (p.1,2 art.75, p. 2 art. 82 CC of the RF);

4) subsidiary responsibility of participants in the company with additional liability for its obligations in the same for all fold to the value of their contributions, determined by the constituent documents of the company (p. 1 art. $95 \mathrm{CC}$ of the RF)

5) subsidiary responsibility of the parent company (partnership) for the debts of the subsidiary in the event of insolvency (bankruptcy) of latest fault of the principal (p.2 art.105 CC of the RF);

6 ) subsidiary responsibility of the members of the production cooperative in the amount and in the manner stipulated by the law on production cooperatives and the charter of the cooperative, for the obligations of the cooperative (p. 2 art. 107 CC of the RF);

7) subsidiary responsibility of the property owner, state-owned enterprises (i.e. founder) for the obligations of the latter with the lack of his property (p. 5 art. $115 \mathrm{CC}$ of the RF);

8) subsidiary responsibility of the members of the consumer cooperative for its obligations within the deposited part of the additional contribution of each member of the cooperative, which they are required to pay within three months after approval of the annual balance in order to cover the resulting losses (p. 4 art. $116 \mathrm{CC}$ of the $\mathrm{RF})$;

9) subsidiary responsibility of the owner of the private property or public institutions (i.e. founder) for the obligations of such institutions with a lack of funds at the disposal of the institution (p. 2 art. 120 CC of the RF);

10) subsidiary responsibility of the members of the Association (Union) for the obligations of the Association (Union) in the amount and in the manner stipulated by the constituent documents of the Association (Union) (p. 4 art. 121 CC of the RF). In the case of withdrawal from the Association (Union) at the end of the financial year former member of the Association (Union) shall bear subsidiary responsibility for obligations of the Association (Union) proportional to its contribution in the two years since the release (p. 2 art. 123 CC of the $\mathrm{RF})$; funding

However, in our case, the state as the founder are not liable, but only in virtue of the law should make additional

The Federal law vested power of bankruptcy trustee on the State Corporation "Agency for deposits insurance". The changes that have occurred in the control system of bankruptcy, are of fundamental importance, since the need for public participation in the management of the bankruptcy of credit institutions is recognized and a special corporate body (Agency) is created through which is provided such public participation. As it is known, the special basis of liquidation of a legal entity is recognized insolvent (bankrupt). However, in the case of public corporations the law establishes that on the data is non-profit organization provisions of the Federal law of October 26, 2002 № 127-FL "On insolvency (bankruptcy)" do not extend (Federal law dated 26.10.2002 No. 127-FL (as amendedit.ed on 29.12.2014) "On insolvency (bankruptcy)", 2014).

Some scholars such an approach of the legislator consider to be incorrect, because the Corporation is a huge, powerful structure that uses huge amounts of money from the Federal budget, which, in fact, monopolized the private sector. (Roi, O.M. and Dening E.N., 2009) It is obvious that the state, by setting such an exception to the General rule, gave the Corporation a special "privileged" position in relation to other entities. Such an exception can be justified by those special "good" purposes for which a public Corporation is created, however, the boundaries of such "promotion" 
must not be contrary to the legal order and all existing legal doctrine. Thus, on the one hand, independent nature of responsibility of the Russian Federation on its obligations and the inability to attract property public corporations for the debts of the state should be welcomed. On the other hand, aims and objectives, which in some cases puts the state before created state corporations, requires more financial costs than the economic contribution of the state when they are created.

\section{Conclusion}

Also should be noted the unacceptable in the conditions of market economy the establishment of exceptions of the Institute of civil liability for public corporations, for example in relation of the state Corporation "Olympstroy", which have the right of refusal unilaterally from the agreement concluded with the performers of works (services) and providing funding for the construction of Olympic facilities and implementation of other related activities for its own account. In our opinion, it violates the fundamental principles and the early civil rights such as freedom of contract, the equality of the parties, judicial protection of violated rights and others, and is subject to cancellation in the prescribed manner.

Thus it can be stated that the choice of the state Corporation as a legal form was largely determined by the possibilities of:

a) simplification of the process of restructuring and consolidation of state ownership in certain sectors;

b) fundamental flexibility in use of funds, identifying areas for possible investment, financing, implementing longterm programs;

c) realization of selective "trimming" of the administrative system

Also very important was the factor of limited time and the desire to overcome the inhibition to address a number of key tasks. In this regard, the establishment of public corporations has become a proactive tool (framework) "institutional fixing" of individual priorities for public policy, the personification of responsibility for the solution of priority tasks.

\section{Acknowlegment}

The article was prepared within the project of the government assignment of the Ministry of education and science "The Legal status of business entities: current status of the Institute and prospects of development" (KlamykSU, project code № 589)

\section{References}

The Federal law from 08.02.1998 No. 14-FL (edit. on 05.05.2014) "About societies with limited liability" // collected legislation of the RF. 16.02.1998. No. 7. - Art. 785.

Federal law dated 26.12.1995 No. 208-FL (edit. on 22.12.2014) "On joint stock companies" // collected legislation of the RF. 01.01.1996. No. 1. - Art. 1.

Civil code of the Russian Federation (part one) from 30.11.1994 \# 51-FL (publ. on 22.10.2014) // collected legislation of the Russian Federation. -05.12.1994. - No. 32. - Art. 3301.

Federal law dated 12.01.1996 No. 7-FL (edit. on 31.12.2014) "On noncommercial organizations" // collected legislation of the RF. 15.01.1996. No. 3. - Art. 145.

Federal law dated 11.06.2003 No. 74-FL (edit. on 23.06.2014) "On peasant (farmer) economy" // collected legislation of the RF. 16.06.2003. No. 24. - Art. 2249.

OECD Guidelines on Corporate Governance of State-owned Enterprises. -Paris, 2005.

The Constitution of the Russian Federation (adopted by popular vote 12.12.1993) // collected legislation of the Russian Federation. 04.08.2014. - No. 31. - Art. 4398.

Federal law dated 26.10.2002 No. 127-FL (as amendedited on 29.12.2014) "On insolvency (bankruptcy)" // collected legislation of the Russian Federation. -28.10.2002. No. 43. -Art. 4190.

Roi O.M. and Dening E.N., 2009 The role of private-public partnerships in the development of high technology//the Initiatives of the XXI century. No. 4. 